\title{
Narrative review: mechanism of ultraviolet radiation-induced basal cell carcinoma
}

\author{
Wanlin Fan $^{1} \wedge$, Alexander C. Rokohl ${ }^{1 \wedge}$, Yongwei Guo ${ }^{1,2} \wedge$, Hong Chen ${ }^{3}$, Tao Gao ${ }^{2}$, Vinodh Kakkassery ${ }^{4}$, \\ Ludwig M. Heindl ${ }^{1,5} \wedge$
}

${ }^{1}$ Department of Ophthalmology, University of Cologne, Faculty of Medicine and University Hospital Cologne, Cologne, Germany; ${ }^{2}$ Eye Center, Second Affiliated Hospital, School of Medicine, Zhejiang University, Hangzhou, China; ${ }^{3}$ Department of Ophthalmology, Union Hospital, Tongji Medical College, Huazhong University of Science and Technology, Wuhan, China; ${ }^{4}$ Department of Ophthalmology, University of Lübeck, Lübeck, Germany; ${ }^{5}$ Center for Integrated Oncology (CIO), Aachen-Bonn-Cologne-Duesseldorf, Cologne, Germany

Contributions: (I) Conception and design: W Fan, LM Heindl; (II) Administrative support: LM Heindl; (III) Provision of study materials or patients: LM Heindl, AC Rokohl, W Fan; (IV) Collection and assembly of data: AC Rokohl, W Fan, Y Guo; (V) Data analysis and interpretation: LM Heindl, V Kakkassery, W Fan; (VI) Manuscript writing: All authors; (VII) Final approval of manuscript: All authors.

Correspondence to: Ludwig M. Heindl, MD. Department of Ophthalmology, Faculty of Medicine and University Hospital Cologne, University of Cologne, Kerpener Strasse 62, 50937 Cologne, Germany. Email: Ludwig.heind1@uk-koeln.de.

Background and Objective: Basal cell carcinoma (BCC) is the most widespread malignant skin cancer and
also the most common cancer in adults. Although its mortality rate is low, its incidence is increasing, especially
in Caucasians. Among many risk factors, ultraviolet radiation (UVR) is the essential factor in forming BCC.
However, the molecular mechanisms leading to transformation are not fully understood. This review provides
a comprehensive description of the interaction of UVR and genetic features in the pathogenesis of BCC, and
specifically, current advances in molecular therapy based on these mechanisms are introduced. Methods: A literature search was performed in the PubMed database using the search algorithms [(basal cell carcinoma) OR (BCC)] AND [(gene mutation) AND (ultraviolet radiation) AND (carcinogenesis)] to identify relevant publications until April 1, 2020. The database search was not restricted to any language, and relevant references were searched from the identified articles.

Key Content and Findings: This review summarizes the potential mechanisms underlying BCC development due to UVR. UVB can be directly absorbed by DNA and induce skin cancer through intracellular signaling leading to DNA damage and altered gene expression. UVA radiation generates reactive oxygen species (ROS), which causes skin cancer through secondary damage to DNA and usually requires long-term cumulative exposure. Cells can repair damaged DNA, but DNA repair may be faulty due to genetic or environmental factors. As a result, mutations in proto-oncogenes and suppressor genes may occur, leading to tumor formation. Various immune responses of the body are usually reduced after UVR. UVR damages DNA, and its repair system alters the immune system and leads to progressive genetic alterations and tumor formation, genetic alterations, and tumor formation. Based on these advances in molecular mechanisms, targeted therapies such as smoothened (SMO) inhibitors (vismodegib and sonidegib), and immunotherapy such as pembrolizumab [anti-programmed cell death-1 (PD-1)] have been developed. Further future studies on the molecular genetics of UVR in the development of BCC may facilitate new targeted therapies and chemoprevention, thus improving treatment efficacy and prevention.

Conclusions: This review highlights UVR damages DNA and its repair mechanisms, suppression the immune system, causes progressive gene mutations, and ultimately leads to tumor formation. Further studies on the molecular mechanisms associated with BCC will help raising public awareness of UV protection and explore new targeted therapeutic and chemopreventive means.

\footnotetext{
^ ORCID: Wanlin Fan, 0000-0001-7143-6707; Alexander C. Rokohl, 0000-0002-0224-3597; Yongwei Guo, 0000-0001-9195-0770; Ludwig M. Heindl, 0000-0002-4413-6132.
} 
Keywords: Basal cell carcinoma (BCC); genetic mutations; ultraviolet radiation (UVR); carcinogenesis

Received: 14 March 2021; Accepted: 30 August 2021; Published online: 08 September 2021.

doi: $10.21037 /$ fomm-21-31

View this article at: https://dx.doi.org/10.21037/fomm-21-31

\section{Introduction}

Non-melanoma skin cancer (NMSC) is the most common type of cancer (1). NMSC mainly includes basal cell carcinoma (BCC) and squamous cell carcinoma (SCC), which account for $70 \%$ and $25 \%$ of NMSC, respectively (1). Both BCC and squamous carcinoma have a good prognosis, especially in their early stages (2). BCC contributes the least to NMSC mortality (MR), with an estimated MR of 0.02 per 10,000 population $(1,2)$. On the other hand, SCC has a variable metastasis rate of $0.1-9.9 \%$ and accounts for approximately $75 \%$ of NMSC deaths $(1,2)$. In whites, approximately $50-70 \%$ of SCCs and $50-90 \%$ of BCCs are caused by ultraviolet (UV) exposure (3).

The most common skin malignancy in Caucasians is BCC, which accounts for approximately $70-80 \%$ of all skin cancers (4). Published epidemiological data show that the incidence of BCC is still on the rise (5). Despite the low mortality rate of BCCs, it can lead to substantial morbidity and cosmetic defects that strongly impact health care budgets due to their remarkable high incidence (6). This type of skin tumor usually occurs in chronically sunexposure sites of the elderly, most commonly on the head and neck (7). Among many etiologies of BCC, the most important is ultraviolet radiation (UVR). It is the leading environmental risk factor for the development of BCC. Some literatures have found that military personnel, engineers, tilers, farmers, lifeguards, mountain guides, and mail carriers more likely to develop skin cancers (mainly basal and SCCs) (8-17). All these individuals have in common the characteristic of being outdoor workers for long periods. Thus, there may be an association between prolonged occupational sun exposure and intense exposure to the sun and inappropriate use of sunscreen during working hours, and the risk of developing NMSC $(8,10,18-20)$. As time goes on, changes in people's dressing style, entertainment, work, lifestyle, and increased life expectancy may lead to increased sun exposure. While most UVR originates from the sun, the incidence of $U V$-induced skin cancer has risen further due to tanning popularity (21). We receive daily UVR exposure from natural and artificial sources. Long-term exposure can lead to photoaging, such as skin wrinkling, roughness, sagging, freckling, and even benign and malignant tumors. It is recognized that UV exposure is a significant risk factor for BCC. However, the molecular mechanisms leading to transformation are not fully understood. Therefore, this article attempts to summarize the current research progress of UVR in the occurrence and development of BCC. We present the following article in accordance with the Narrative Review reporting checklist (available at https://fomm.amegroups. com/article/view/10.21037/fomm-21-31/rc).

\section{Methods}

In this study, we developed a comprehensive search in the PubMed database until April 1, 2020 by using the following algorithms [(basal cell carcinoma) OR (BCC)] AND [(gene mutation) AND (ultraviolet radiation) AND (carcinogenesis)]. The database search was not restricted to any language, and relevant references were searched from the identified articles (Table 1).

\section{Discussion}

\section{UVR and BCC}

Sunlight consists of a continuous ionization spectrum that includes UVR (100-400 $\mathrm{nm})$, visible light $(400-760 \mathrm{~nm}$ ), and infrared radiation (IR; $760 \mathrm{~nm}-1 \mathrm{~mm}$ ). This spectrogram is shown in Figure 1. UVR is further divided into three ranges according to the wavelength: UVA (315-400 nm), UVB (280-315 nm), and UVC (100-280 nm). Most UVB and all UVC (wavelengths below $280 \mathrm{~nm}$ ) are removed by the ozone layer, and these shorter wavelengths do not occur in incident sunlight (22). UVA radiation (90-95\%) is the most extensive UVR to reach the Earth's surface, and it extends deep into the cutaneous dermis. Only $5-10 \%$ of UVB radiation reaches the Earth's surface and is mostly absorbed by the epidermis. However, the efficiency of UVA-induced biological effects (expressed as the minimum amount of 


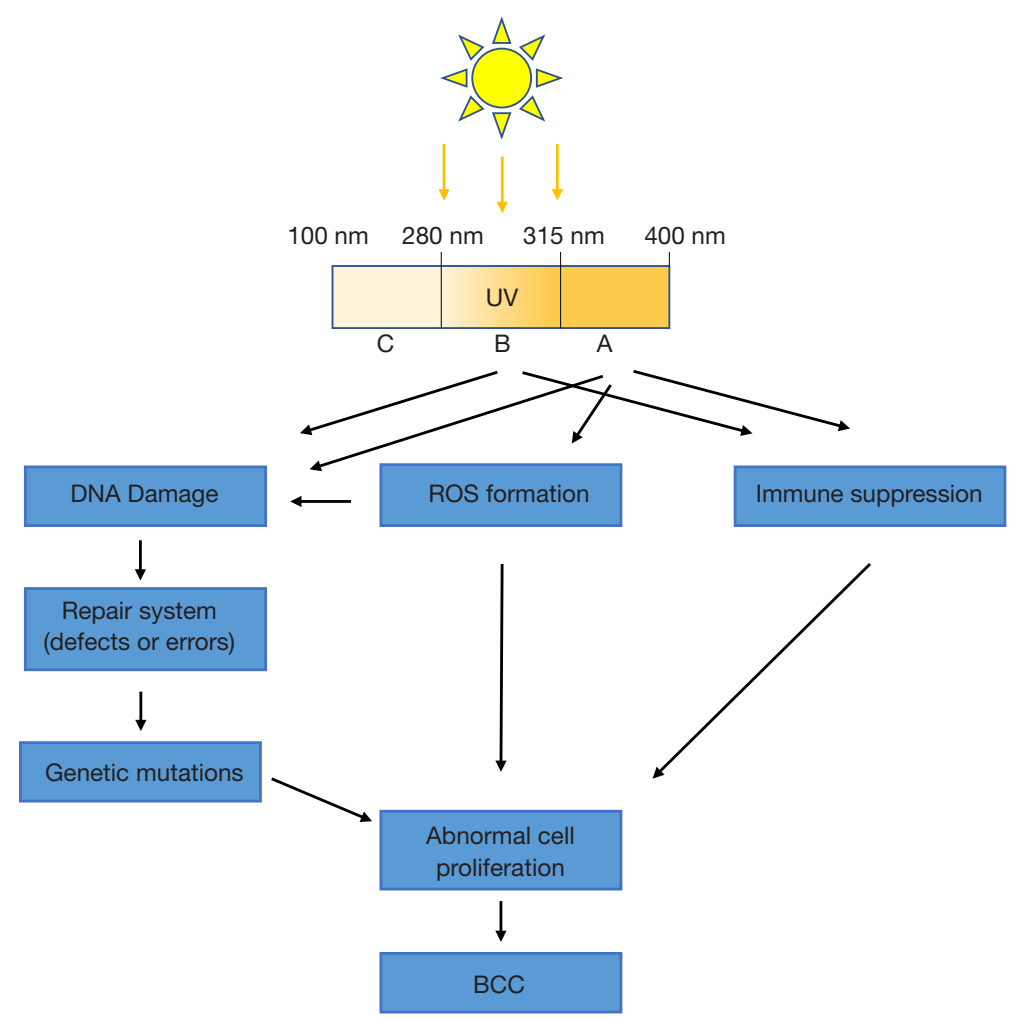

Figure 1 Overview of UV radiation and basal cell carcinoma: Solar UV radiation is mainly of UVA, UVB and UBC types, the first two types of UV radiation cause immunosuppression and DNA damage to human skin. UVA causes DNA damage through ROS, while UVB directly causes DNA damage and immunosuppression, which eventually leads to the formation of basal cell carcinoma. BCC, basal cell carcinoma; ROS, reactive oxygen species; UV, ultraviolet.

erythema) is 1,000 times lower than that of $\operatorname{UVB}(23,24)$. The effects of UVB are mainly mediated by chromophores (24-27). At the same time, moderate doses of UVB have significant positive effects on all organisms on Earth, including humans. UVB can induce the production of vitamin $\mathrm{D}$ in the skin. In fact, active forms of vitamin D can play important role in photoprotection (28) and skin cancer (29). Vitamin D deficiency $(20 \mathrm{ng} / \mathrm{mL})$ is associated with increased incidence and worse prognosis in various types of cancer, including melanoma (30). In contrast, the phenotypic effects of UVA, although weakly absorbed by DNA and a limited number of cellular chromophores (including NADH, reduced NADP, riboflavin, and porphyrins), are mainly caused by cellular oxidative changes induced by reactive oxygen species (ROS) $(24,26,27)$. Several studies have found that the ozone layer has decreased with the increased use of chlorofluorocarbon (CFC)containing products (31). Depletion of the ozone layer and increased cumulative UV exposure may be responsible for the increased risk of skin cancer in humans with increased longevity (32). The skin is a protective barrier organ with self-regulating sensory and computational capabilities to counteract environmental stresses and maintain and restore balance to damaged skin (25). These complex functions are coordinated by the cutaneous neuroendocrine system, which also communicates in both directions with the central nervous, endocrine, and immune systems, all of which are consistent with controlling the body's dynamic balance $(25,33)$. Although UV is a crucial determinant of the origin and evolution of life on Earth (34), UV absorption by the skin not only stimulates mechanisms that protect skin integrity and maintain global dynamic homeostasis, but it also induces the development of skin pathologies such as cancer, aging, and autoimmunity (35). After absorbing electromagnetic energy and converting it into chemical, hormonal and neural signals in a wavelengthdependent manner, UV regulates global dynamic homeostasis, depending on its tissue penetration and the 
Table 1 The search strategy summary

\begin{tabular}{ll}
\hline Items & Specification \\
\hline Date of search & April 1, 2020 \\
Databases and other sources searched & PubMed database \\
Search terms used & {$[$ (basal cell carcinoma) OR (BCC)] AND [(gene mutation) AND (Ultraviolet radiation) AND } \\
& (carcinogenesis)] \\
Timeframe & Until April 1, 2020 \\
Inclusion and exclusion criteria & No searching restrictions \\
Selection process & Wanlin Fan conducted the selection \\
\hline
\end{tabular}

Table 2 Clinical subtypes of basal cell carcinoma

\begin{tabular}{|c|c|}
\hline Subtypes of BCC & Clinical characteristics \\
\hline Micronodular & Erythema or thin papules/plaques \\
\hline Morpheaform & Infiltrative plaques with faint borders and shiny surfaces, commonly on the head and neck \\
\hline Infundibulocystic & Well-defined pearly papules on the head and neck are common in the elderly \\
\hline Fibroepithelial & Sessile patches of skin color or erythema or pedunculated papules with a predilection for the trunk (49) \\
\hline
\end{tabular}

BCC, basal cell carcinoma.

nature of the chromophores with which UV interacts. This balancing activity is achieved by activating the central nervous system and/or endocrine glands through neurotransmission or chemical messengers in the skin (35). And this type of regulation follows precise neuroendocrine regulatory mechanisms such as hypothalamic-pituitaryadrenal (HPA) (36), corticotrophin-releasing hormoneproopiomelanocortin (CRH-POMC) $(37,38)$, opioids (39), serotonin/melatonergic $(27,40,41)$, secosteroid/ steroidogenic (42-44), or NO systems $(45,46)$.

Several clinical subtypes of BCC include nodular, superficial, micronodular, infiltrative, morphologic, infudibulocystic, etc. (47-52) (Table 2). Among them, nodular, superficial, and morphologic BCCs are the most common clinical subtypes $(47,53)$. Different clinical subtypes vary in terms of clinical presentation, histopathology, and aggressive behavior. Based on various prognostic factors, BCC can be classified as low, and high risk (54) (Table 3).

According to several epidemiological investigations, BCC incidence was found to be less correlated with lifetime cumulative sun exposure and more likely to be associated with intermittent (recreational) sun exposure and childhood exposure (55). Recreational activities, such as sunbathing or water sports on the beach, are associated with an increased incidence of BCC. However, spectators of outdoor sports activities are often unaware of sun exposure dangers (56). In addition to occupational and recreational UV exposure, UV phototherapy has been associated with BCC development.

\section{UV impact on BCC}

$\mathrm{UV}$-induced skin carcinogenesis is a complex and sequential 
Table 3 Low- and high-risk features of basal cell carcinomas

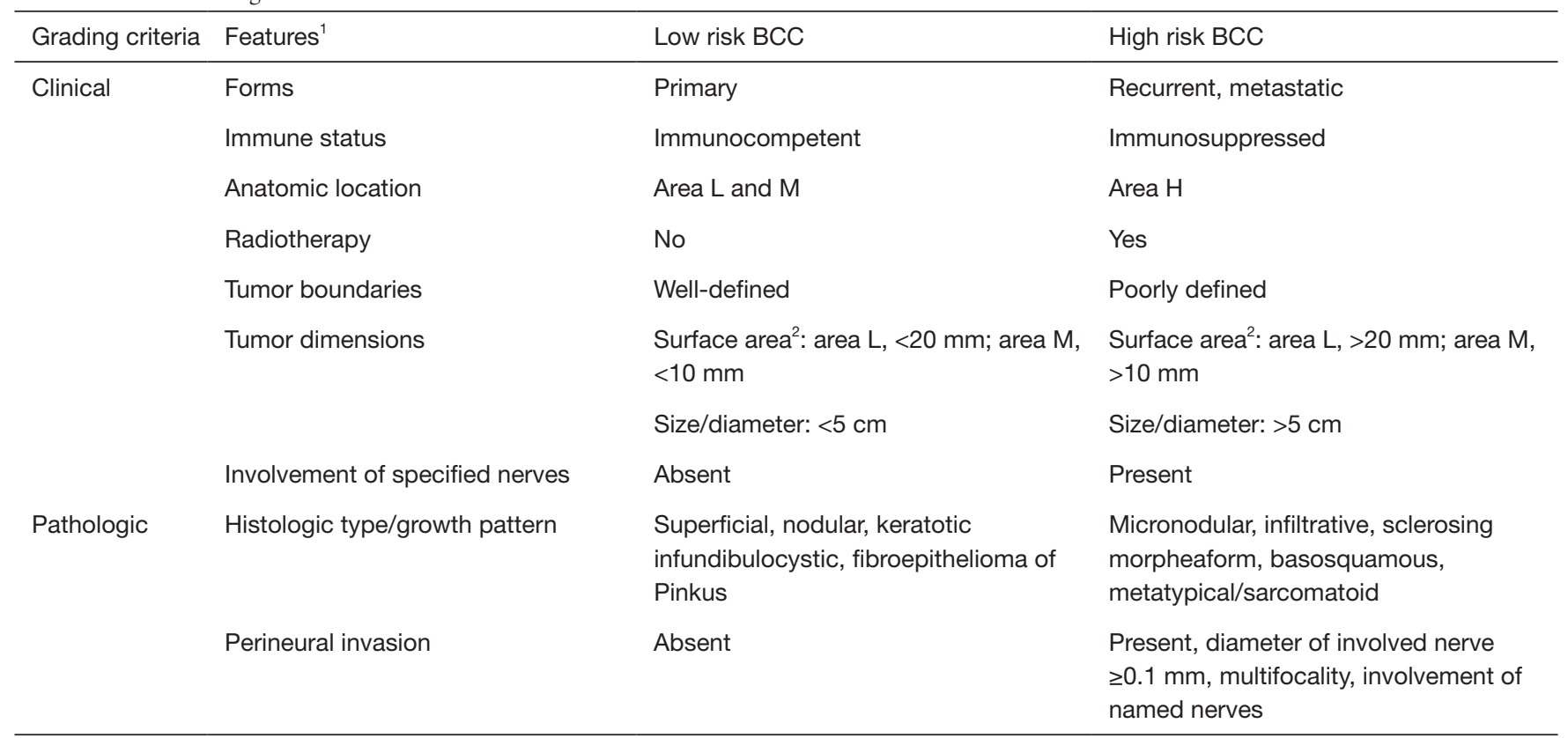

${ }^{1}$, features as defined by the National Comprehensive Cancer Network; ${ }^{2}$, human skin is divided into three zones according to the risk of invasive keratinocyte carcinoma: area $\mathrm{H}$ is a high-risk zone (frontal hairline, central face, nose, eyelids, chin, ears, genitalia, hands, feet, and bald scalp); area $\mathrm{M}$ is a medium-risk zone (cheeks, forehead, scalp, neck, and jawline); and area $\mathrm{L}$ is a low-risk zone (trunk and extremities, excluding areas $\mathrm{H}$ and $\mathrm{M})$. BCC, basal cell carcinoma.

biological process caused by different wavelengths of UV light. UVB can be absorbed directly by DNA, leading to DNA damage and altered gene expression through intracellular signal transduction, which can induce skin cancer. UVA radiation generates ROS, which cause skin cancer through secondary damage to DNA and generally requires chronic cumulative exposure. Cells could repair damaged DNA, but DNA repair may go wrong due to genetic or environmental factors. Therefore, the mutation of proto-oncogenes and suppressor genes may occur, leading to the formation of tumors. Various immune responses of the organism are usually decreased after UV irradiation, which we call immunosuppression. UVR causes damage to DNA and its repair system and changes the immune system, leading to progressive genetic changes and tumor formation (57).

\section{UVR-induced DNA damage}

UVB can penetrate several layers of cells into the dermis and perhaps basal cells. The forms of UVB-induced DNA photodamage include pyrimidine dimers, purine and pyrimidine dimers, purine photoproducts, protein-DNA crosslinks single-strand breaks. The most important one is pyrimidine dimers (58).

The direct absorption of UVB photons by DNA bases leads to photoproducts between two adjacent pyrimidine sites [thymine-thymine (TT), cytosine-thymidine (CT), thymidine-cytosine (TC), cytosine-cytosine (CC)] on the same DNA strand. Products include cyclobutane pyrimidine dimer (CPD) and 6-pyrimidine-4-pyrimidinone photoproduct (6-4 PP). Both are essential prerequisites for the increased frequency of mutations and underlie skin cancer induction by UV exposure. Cells can repair 6-4 PP more efficiently. The TC and CC dimers of CPD are the most mutagenic because, in $\mathrm{UV}$-induced skin cancer, the $p 53$ gene often shows $\mathrm{C} \rightarrow \mathrm{T}$ and $\mathrm{CC} \rightarrow \mathrm{TT}$ mutations, hence the term UV signature mutation (59). The major photoproduct TT dimer is rarely mutated due to DNA polymerase's repair effect. UVB induces dimer formation through adenine residues and thymine residues on the DNA strand. Although limited in number, such dimers have been shown to cause mutations (59). UVB can also induce guanine oxidation to produce the purine photoproduct 8 -hydroxy-2'-deoxyguanosine (8-OHdG). 8 -OHdG is a general marker of oxidative stress. Although it accounts for only a small fraction of medium-wave UVB damage, it 
can induce $\mathrm{G} \rightarrow \mathrm{T}$ translocation, leading to gene mutations. Besides the above three DNA damages, UVB radiation causes other DNA damage types, such as protein-DNA cross-linking and single-stranded DNA breaks (60).

\section{UVR-induced DNA repair}

Normal human keratinocytes harbor an effective DNA damage repair system that prevents multiple genetic mutations induced by UV damage. Signaling pathways for DNA damage repair include DNA double-strand break repair (DSB), nucleotide excision repair (NER), base excision repair (BER), mismatch repair (MMR), and postreplication repair (PRR) (61-64). Two major DNA repair systems play a crucial role in UV-induced damage: the NER and BER systems. The NER plays a crucial role in repairing CPDs and 6-4 PPs (65-68).

The BER system can repair single base lesions such as 8-OHdG. This pathway involves depurine/depyrimidine site nucleic acid endonucleases (APEX1/REF-1), proliferating cell nuclear antigen (PCNA), replication protein A (RPA), and enzymatic glycosylation (69). Commonly, glycosylases recognize the lesion, severing the base's glycosyl bond and the leading DNA strand. The lesion presents as a basic site (AP site), identified by the APEX1/REF-1 protein. The APEX1/REF-1 protein produces a single-strand break (a nick site), then repaired by DNA polymerase I and DNA ligase III (69). The BER system activity is controlled by the HOGG1 and inhibited by nitric oxide (NO) (70). Therefore, UVR-induced NO not only leads to DNA damage but also suppresses the BER system's activity, contributing to an increase in gene mutations and the risk of skin cancer (69).

\section{UVR-induced DNA mutation}

Basal cell carcinogenesis is the result of the interaction of multiple genetic and environmental factors. Significantly, most of the genes involved in the pathogenesis of BCC exhibit mutational features consistent with $\mathrm{UV}$-induced DNA damage. After UV irradiation, cells normally repair CPD and 6-4 PP lesions through the repair system. However, if the repair system is defective or occasionally repair errors occur, DNA damage will result in genetic mutations. Mutations may affect cell cycle regulation, leading to clonal proliferation and immortalized growth, eventually causing BCC.

\section{Hedgehog $(\mathrm{HH})$ pathway genes}

The HH pathway is a highly conserved developmental pathway involved in organogenesis, stem cell maintenance, tissue repair, and regeneration. In the skin, it maintains stem cell populations and controls the development of hair follicles and sebaceous glands (71). The HH pathway is mainly inactive in adults, except for its functions in tissue repair and maintenance (72). The major components of the $\mathrm{HH}$ pathway include three secreted ligands [sonic $\mathrm{HH}$ (SHH), Indian $\mathrm{HH}$, and desert $\mathrm{HH}$, a negatively regulated receptor [Patched (PTCH)], a positively regulated receptor [smoothened (SMO)], and glioma-associated oncogene (GLI) transcription factors (GLI1, GLI2, and GLI3) $(72,73)$. HH signaling relies on primary ciliary structures, which are highly specialized microtubule-based organelles that protrude from its plasma membrane in nearly all types of cells and act as sensors of extracellular signals $(74,75)$. Usually, extracellular HH ligands bind to PTCH1 receptors, thereby relieving the inhibitory effect of PTCH1 on SMO. Active SMO migrates to primary cilia, a highly specialized microtubule organelle that acts as a sensor of extracellular signals. SMO activates a signaling cascade of interacting proteins, including a repressor of fusion (SUFU), which leads to activation of the GLI family of transcription factors. In the lack of $\mathrm{HH}$ ligand, PTCH localizes to cilia and inhibits SMO activity by blocking SMO transport and localization to cilia (76). GLI transcription factors are sequestered in the cytoplasm through various protein mediators such as protein kinase A (PKA) and SUFU. GLI undergoes protease cleavage and the resulting blockers form GLI translocations to the nucleus, thereby repressing translation of $\mathrm{HH}$ target genes (Figure 2A) (76).

Aberrant $\mathrm{HH}$ signaling activation is a hallmark of basal cell carcinogenesis (77). A recent study indicated that over $85 \%$ of BCCs have defects in the HH signaling pathway $(78,79)$. Somatic mutations in PTCH were found in $90 \%$ of sporadic BCC (80), and gain-of-function mutations in SMO were detected in BCC (81). In particular, recurrent mutations and functional studies in SMO have shown that these mutations lead to abnormal activation of HH signaling and promote tumor development (Figure 2B) (81). The frequency of PTCH mutations in $\mathrm{BCC}$ patients has been reported to be $11-75 \%$ (73,78,80,82-89). About half of these mutations carry the $\mathrm{UV}$ signature (i.e., $\mathrm{C} \rightarrow \mathrm{T}$ and $\mathrm{CC} \rightarrow \mathrm{TT}$ transitions at the pyrimidine locus) $(78,83-85,88-90)$, and these mutations are associated with radiation dose. However, the mutation was not present in SCC, suggesting that PTCH mutations are critical in BCC but not in SCC.

In addition to the canonical $\mathrm{HH}$ pathway, which relies on HH-PTCH1 binding and SMO activation, transcriptional 


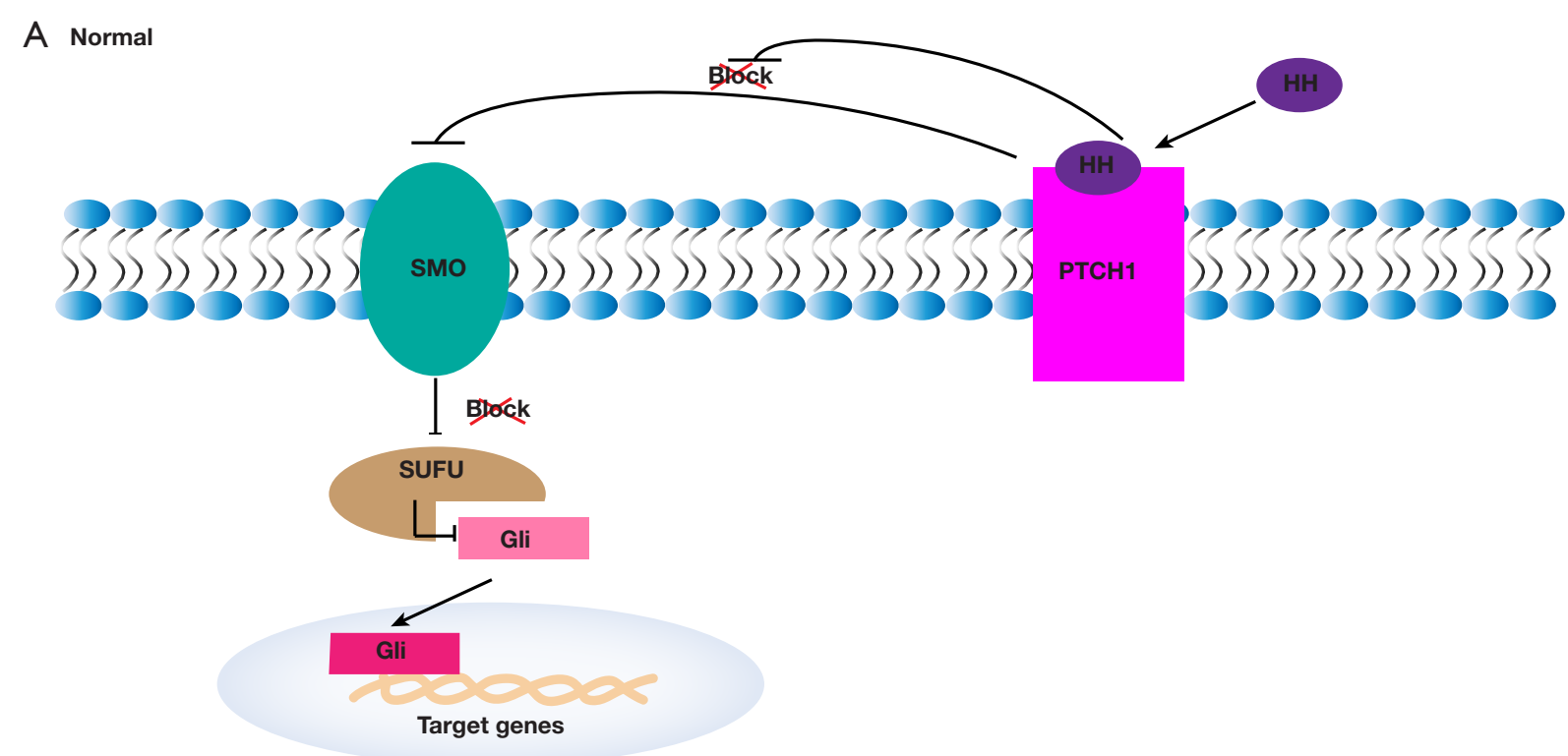

B BCC

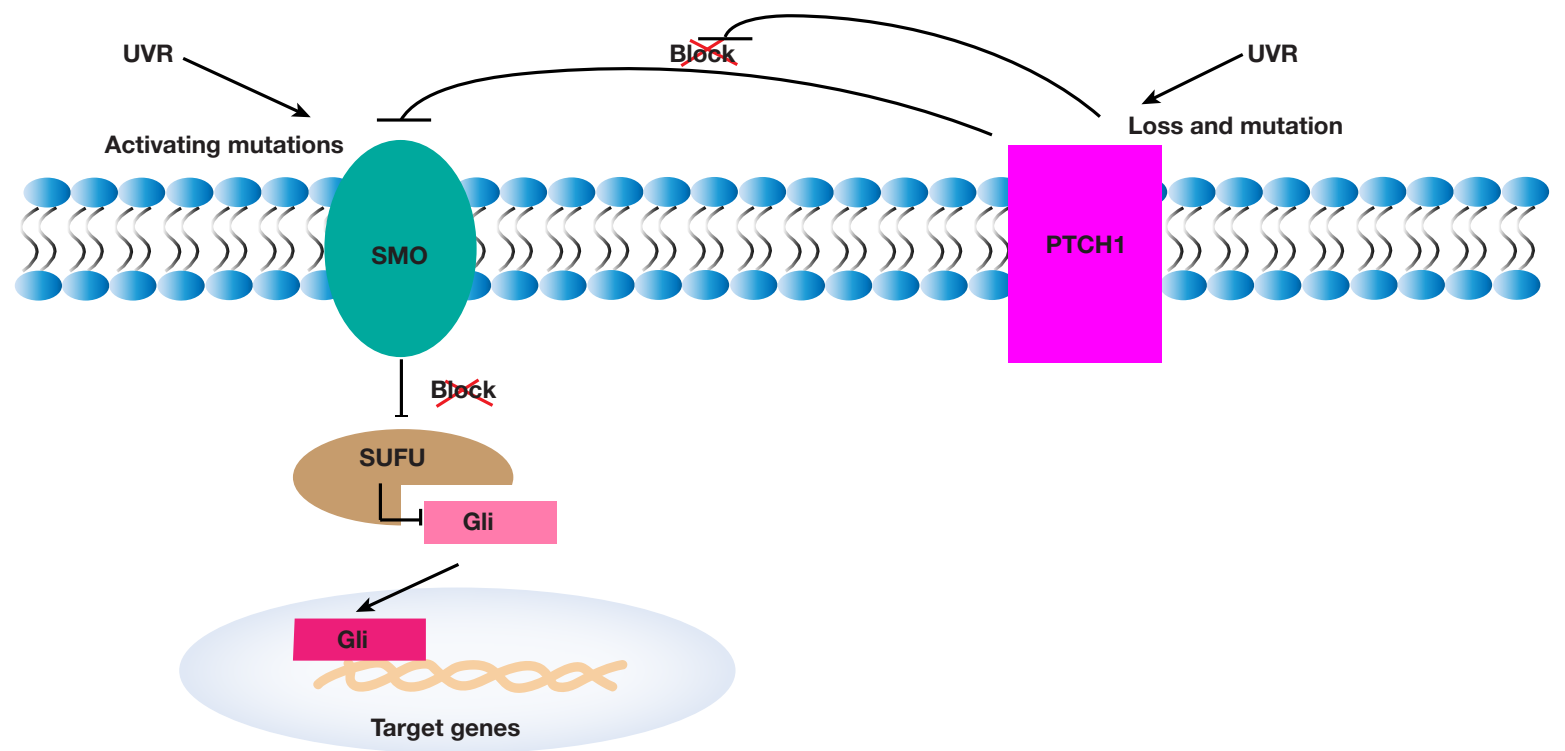

Figure $2 \mathrm{HH}$ pathway in embryonic development (A) and basal cell carcinoma (B). HH, Hedgehog; BCC, basal cell carcinoma; SMO, smoothened; Gli, glioma-associated oncogene; UVR, ultraviolet radiation.

or post-translational modification of GLI can be executed by interacting with various other different oncogenic signaling networks [epidermal growth factor receptor (EGFR), insulin-like growth factor (IGF), transforming growth factor (TGF) $\beta$, protein kinase $\mathrm{C}$, (phosphoinositide 3-kinase (PI3K), and nuclear factor $\kappa \mathrm{B}(\mathrm{NF}-\kappa \mathrm{B})]$. Noncanonical HH signaling pathways (e.g., EGFR, IGF, TGF pathways) may synergistically promote BCC development through transcriptional or post-translational modifications of GLI bypassing HH-mediated SMO activation $(77,91,92)$. RAS, TGF, PI3K/AKT, NF- $\kappa$ B, and atypical protein kinase $\mathrm{C} 1 / \lambda(\mathrm{aPKCl} / \lambda)$ can positively regulate GLI activity, and p53 and PKA negatively regulate GLI activity. The noncanonical regulation of GLI may partly explain the failure of some SMO antagonists in clinical trials. For example, high levels of $\mathrm{PKCl} / \lambda$ were found in basal cells resistant to Vismodegib (93). Therefore, the use of SMO or GLI antagonists in combination with therapeutic strategies 
capable of inhibiting atypical $\mathrm{HH}$ signaling may reduce the incidence of resistance. Interestingly, topical treatment with imiquimod enhances PKA activity, which leads to GLI phosphorylation and cleavage into its blocker form (94).

\section{P53 gene}

Basal cell carcinogenesis is associated with the inactivation of the P53 gene. The oncogene P53 is involved in the regulation of the cell cycle and the activation of programmed cell death $(95,96)$. As a gatekeeper of the genome, P53 monitors the integrity of the genome. Once a cell undergoes DNA damage, P53 activates cell cycle checkpoints to repair the damaged DNA. If the repair fails, P53 can cause programmed cell death, thereby preventing mutant cells' production. When various carcinogens inactivate P53, it cannot repair DNA damage and fails to initiate programmed cell death when repair fails, ultimately leading to cell transformation (58). About $50 \%$ of BCCs have detectable P53 mutations. Most of the mutations are C-T, CC-TT alterations, which indicate the importance of UV in BCC with P53 gene mutations (90, 97-99). One study found that lower levels of $P 53$ mutations were indeed found in BCC patients who used sunscreen compared to those who did not use sunscreen (100).

\section{RAS gene}

RAS genes are divided into three proto-oncogenes, H-ras, $\mathrm{K}$-ras, and $\mathrm{N}$-ras, which together encode $21 \mathrm{kDa}$ proteins. These three genes share $70 \%$ homologous sequences (101). RAS proteins are located on the inner surface of cells and bind to GTP, thus participating in signal transduction. It was found that RAS mutations occurred mainly at codons 12,13 , and 61 (102). When bound to GTP, the RAS gene is activated. The mutation may lead to activation by decreasing the rate of hydrolysis of GDP by GTP. However, RAS genes do not seem to be common in BCC at present.

\section{UVR-induced immunosuppression}

UVR-induced immunosuppression plays a crucial role in skin carcinogenesis (103). UVR production such as CPDs has been reported to cause immunosuppression (104). UVR significantly reduces the antigen-presenting capacity of skin dendritic cells, thereby suppressing the local immune response (Langerhans) and promoting the evasion of tumor immune surveillance by premalignant and early melanoma cells $(36,37,103,105)$. Furthermore, exposure to UVB promotes the migration of UVR-damaged Langerhans cells to regional lymph nodes, which leads to the expansion of regulatory $\mathrm{T}$ cells and decreases effector and memory
$\mathrm{T}$ cells, resulting in suppression of the adaptive immune system $(105,106)$. UVR also stimulates other molecules with immunosuppressive properties such as prostaglandins, platelet-activating, IL-10, and ROS (107).

UVB is a significant skin stressor that, on the one hand, causes several skin lesions, including cancer (108-110), and on the other hand, is necessary for vitamin D production $(111,112)$, activation of local neurohormones $(25,38)$ and stimulation of melanin deposition (4,34,38-40,109,113-116). UVB induces the production of POMC peptides that are immunosuppressive $(33,37,38)$ and glucocorticoids at local and systemic levels (117-119). Cutaneous melanin pigments play a crucial role in protection from the harmful effects of solar radiation. Melanin formation is complexly regulated by multiple factors that interact in a hormonal, automatic, quasi-automatic, or endocrine manner through pathways activated by receptor-dependent and non-dependent mechanisms (115). The above findings fully illustrate the apparent relationship between UVR and immunosuppression in skin cancer formation.

\section{Treatment of BCC}

\section{Surgery}

The treatment of BCC is usually determined by patient characteristics, such as comorbidities and ages, and tumor characteristics, classified into low- and high-risk tumors (Table 2). The majority of treatment options for primary BCC are surgical, including resection with postoperative margin evaluation and Mohs micrographic surgery (MMS) $(120,121)$. Low-risk primary BCC is usually treated using surgical resection. High-risk BCC may then be considered for MMS, especially for sclerosis, recurrence, large BCCs, poorly defined, and tumors in anatomic areas that require tissue preservation, such as the eyes, nose, lips, and ears $(122,123)$.

\section{Non-surgical destructive treatments}

Non-surgical destructive treatments include electrodissection and curettage (EDC) and cryosurgery. EDC uses electricity to destroy the remaining cancer cells in the tumor bed when scraping the tumor from the skin and is mainly applied to low-risk BCC in non-hairy areas of the extremities and trunk $(122,123)$. Cryosurgery uses liquid nitrogen to destroy tumor cells through a freeze-thaw cycle and is suitable for low-risk tumors where other effective treatments are limited (122-126). 


\section{Light-based therapy}

Light-based therapies mainly use discrete wavelengths of light to target BCC and can be divided into photodynamic therapy (PDT) and laser. PDT uses photosensitizers to wake up in rapidly dividing cells selectively, and the ROS produced destroys the rapidly proliferating cancer cells when exposed to the light source. PDT can be used to treat low-risk superficial tumors in non-hairy areas. Laser therapy is used to ablate skin cancers with a carbon dioxide laser $(122,127)$. Alternatively, a pulsed dye laser is employed to selectively convert light into heat energy within the blood vessels, thereby destroying tumor tissue $(128,129)$.

\section{Radiation therapy}

In radiation therapy, high-energy rays such as X-rays or particles (photons, electrons, or protons, most commonly electron beams) are traditionally used to destroy BCC $(122,130)$. X-ray brachytherapy can also be administered to the tumor with the aid of a shielded surface. Radiation therapy can be given first when surgery is not feasible for low-risk tumors. Radiotherapy should not be used for skin cancer patients who have genetic disorders (e.g., basal cell nevus syndrome, erythroderma) or connective tissue diseases (e.g., lupus, scleroderma). It is also not recommended for patients younger than 60 years of age (131).

\section{Topical treatment}

Topical treatment regimens are usually appropriate for superficial BCC, including 5-fluorouracil (132), imiquimod (132), tazarotene (133), ingenol mebutate (134) and diclofenac (135). Dosing regimens and outcomes vary between drugs and are influenced by tumor location, side effects, and patient compliance. Patients with contraindications to surgery could be treated with intratumoral drug injections (e.g., methotrexate, 5 -fluorouracil, bleomycin, or interferon) (136).

\section{Molecular therapy}

Identifying tumor-specific genetic alterations is currently one of the hottest areas of cancer research, and the resulting new molecular therapeutic approaches include mainly target therapy and immunotherapy.

\section{Target therapy}

Targeted therapy is available for patients with metastatic BCC or locally advanced unresectable BCC. This therapy focuses on SMO inhibitors (vismodegib and sonidegib) to inhibit the activation of the SHH signaling pathway that is frequently mutated in BCC (137-141). The FDA approved Vismodegib in 2012 for the treatment of local advanced or metastatic BCCs (142). Follow-up studies found objective efficacy rates of $48 \%$ and $33 \%$ in patients with locally advanced and metastatic BCC, respectively (143). However, almost all patients experienced at least one of the following adverse reactions: hair loss, muscle cramps, weight loss, postural disturbances, diarrhea, or fatigue. And grade 3 or 4 adverse reactions occurred in $25 \%$ of patients (144). Another study showed that vismodegib significantly reduced the incidence of new BCC and the size of existing tumors. However, only $17 \%$ of patients were able to tolerate the drug consistently throughout the study period. Hepatotoxicity has also been reported, and the drug should be used with caution in patients with severe liver disease (145).

A second $\mathrm{HH}$ pathway inhibitor, sonidegib, is approved by the FDA to treat locally advanced BCC that has recurred after surgery or radiation therapy or that cannot be treated with surgery or radiation therapy. A clinical (BOLT) trial of LDE225 found response rates of $44 \%$ to $58 \%$ for locally advanced BCC and $8 \%$ to $17 \%$ for metastatic BCC (146). Notably, Hou et al. recently reported that the first successful case of periocular locally advanced BCC with oral sonidegib (141). However, almost all patients experienced at least one adverse reaction, with the most commonly occurring grade 3 or 4 adverse reactions being creatinine kinase and lipase elevations. Unlike vismodegib, sonidegib should be taken on an empty stomach and should not be used concomitantly with potent or moderate CYP3A inhibitors (147).

\section{Immunotherapy}

Immunotherapy blocks immune checkpoint proteins by monoclonal antibodies such as anti-programmed cell death-1 (PD-1) and PD-ligand-1 (PD-L1), thereby enhancing the anti-tumor immune response. Several immune-related markers have been found to correlate with the pathogenesis of BCC (148-153), suggesting the potential use of immunotherapy to treat BCC. Recent case reports have found the efficacy of anti-PD-1 therapy for advanced BCC, both on initial treatment and after developing resistance to $\mathrm{HH}$ pathway inhibitors (154-156). The effectiveness of pembrolizumab (anti-PD-1) in combination with vismodegib for the treatment of metastatic or unresectable BCCs is being studied (NCT02690948) in a phase 1 clinical trial (157). 


\section{Prevention of UVR-induced BCC}

As solar UVR is the most important environmental risk factor for the development of BCC (158), protection against UVR is a fundamental approach to preventing BCC. The measures include avoiding direct exposure to the sun at noon (10 a.m. to 2 p.m.), taking care not to get burned, avoiding tanning and avoiding tanning beds; taking special care near water, snow, and sand; taking care to find shade; wearing protective clothing, hats, and sunglasses when necessary; applying sunscreen to protect against UVA and UVB radiationinduced immunosuppression and DNA damage (159) as well as regular whole-body skin cancer screening (160).

Furthermore, new chemoprevention methods have emerged, such as the use of nicotinamide (vitamin B3) (161). Vitamin B3 prevents ATP depletion and glycolytic blockage caused by UVR, thus enhancing cellular DNA repair. It also reduces radiation-induced immunosuppression. A series of studies (161-163) concluded that nicotinamide $(500 \mathrm{mg} / \mathrm{d}$ twice/d) could be an effective method for preventing BCC, especially for secondary prevention in high-risk patients with existing BCC. Besides, some studies have found that the cyclooxygenase-2 (COX-2) inhibitor celecoxib reduces the risk of BCC $(164,165)$. Due to the lack of relevant evidence and conflicting results, it is currently not recommended for chemoprevention (166). PDT may reduce the incidence of actinic keratoses (AK) cases (167), but its preventive effect on BCC has been rarely reported and needs to be validated in more extensive studies (168).

Long-term monitoring is also essential for patients with BCC. In the National Comprehensive Cancer Network (NCCN) guidelines, it is recommended that patients with BCC undergo a whole-body skin examination every 6 months to 1 year for the first 2 years after diagnosis and then annually after that (169). Patients are also encouraged to self-monitor.

\section{Conclusions}

No doubt, UVR is a fundamental cause of BCC. The role and mechanism of UVR in the development of $\mathrm{BCC}$ are discussed in detail. Therefore, physicians should educate the public about the importance of UV protection in preventing BCC. Meanwhile, the further study of the molecular genetics of UVR in the development of BCC may promote new targeted therapies and chemoprevention, resulting in improved therapeutic efficacy and prevention.

\section{Acknowledgments}

Funding: This study was supported by the State Scholarship Fund from China Scholarship Council, China (No. 202008080258).

\section{Footnote}

Provenance and Peer Review: This article was commissioned by the editorial office, Frontiers of Oral and Maxillofacial Medicine for the series "Diagnosis and Treatment of Periorbital Basal Cell Carcinoma". The article has undergone external peer review.

Reporting Checklist: The authors have completed the Narrative Review reporting checklist. Available at https://fomm. amegroups.com/article/view/10.21037/fomm-21-31/rc

Conflicts of Interest: All authors have completed the ICMJE uniform disclosure form (available at https://fomm. amegroups.com/article/view/10.21037/fomm-21-31/coif). The series "Diagnosis and Treatment of Periorbital Basal Cell Carcinoma" was commissioned by the editorial office without any funding or sponsorship. LMH and VK served as the unpaid Guest Editors of the special. LMH serves as an unpaid editorial board member of Frontiers of Oral and Maxillofacial Medicine from September 2020 to August 2024. The authors have no other conflicts of interest to declare.

Etbical Statement: The authors are accountable for all aspects of the work in ensuring that questions related to the accuracy or integrity of any part of the work are appropriately investigated and resolved.

Open Access Statement: This is an Open Access article distributed in accordance with the Creative Commons Attribution-NonCommercial-NoDerivs 4.0 International License (CC BY-NC-ND 4.0), which permits the noncommercial replication and distribution of the article with the strict proviso that no changes or edits are made and the original work is properly cited (including links to both the formal publication through the relevant DOI and the license). See: https://creativecommons.org/licenses/by-nc-nd/4.0/.

\section{References}

1. Leiter U, Eigentler T, Garbe C. Epidemiology of skin cancer. Adv Exp Med Biol 2014;810:120-40. 
2. Apalla Z, Nashan D, Weller RB, et al. Skin Cancer: Epidemiology, Disease Burden, Pathophysiology, Diagnosis, and Therapeutic Approaches. Dermatol Ther (Heidelb) 2017;7:5-19.

3. Larese Filon F, Buric M, Fluehler C. UV exposure, preventive habits, risk perception, and occupation in NMSC patients: A case-control study in Trieste (NE Italy). Photodermatol Photoimmunol Photomed 2019;35:24-30.

4. Wong CS, Strange RC, Lear JT. Basal cell carcinoma. BMJ 2003;327:794-8.

5. Lai V, Cranwell W, Sinclair R. Epidemiology of skin cancer in the mature patient. Clin Dermatol 2018;36:167-76.

6. Verkouteren JAC, Ramdas KHR, Wakkee M, et al. Epidemiology of basal cell carcinoma: scholarly review. $\mathrm{Br}$ J Dermatol 2017;177:359-72.

7. Kumar R, Deep G, Agarwal R. An Overview of Ultraviolet B Radiation-Induced Skin Cancer Chemoprevention by Silibinin. Curr Pharmacol Rep 2015;1:206-15.

8. Zink A, Tizek L, Schielein M, et al. Different outdoor professions have different risks - a cross-sectional study comparing non-melanoma skin cancer risk among farmers, gardeners and mountain guides. J Eur Acad Dermatol Venereol 2018;32:1695-701.

9. Fartasch M, Diepgen TL, Schmitt J, et al. The relationship between occupational sun exposure and non-melanoma skin cancer: clinical basics, epidemiology, occupational disease evaluation, and prevention. Dtsch Arztebl Int 2012;109:715-20.

10. Trakatelli M, Barkitzi K, Apap C, et al. Skin cancer risk in outdoor workers: a European multicenter casecontrol study. J Eur Acad Dermatol Venereol 2016;30 Suppl 3:5-11.

11. Modenese A, Korpinen L, Gobba F. Occupational skin cancer in outdoor workers in italy: expected number vs cases recognised by the italian national compensation authority (inail). Occup Environ Med 2018;75:A430.

12. Modenese A, Farnetani F, Andreoli A, et al. Questionnairebased evaluation of occupational and non-occupational solar radiation exposure in a sample of Italian patients treated for actinic keratosis and other non-melanoma skin cancers. J Eur Acad Dermatol Venereol 2016;30 Suppl 3:21-6.

13. Walkosz BJ, Buller DB, Andersen PA, et al. Factors Associated With Occupational Sun-Protection Policies in Local Government Organizations in Colorado. JAMA Dermatol 2015;151:991-7.

14. Duffy SA, Choi SH, Hollern R, et al. Factors associated with risky sun exposure behaviors among operating engineers. Am J Ind Med 2012;55:786-92.

15. Reinau D, Weiss M, Meier CR, et al. Outdoor workers' sun-related knowledge, attitudes and protective behaviours: a systematic review of cross-sectional and interventional studies. Br J Dermatol 2013;168:928-40.

16. Kütting B, Drexler H. UV-induced skin cancer at workplace and evidence-based prevention. Int Arch Occup Environ Health 2010;83:843-54.

17. Riemenschneider K, Liu J, Powers JG. Skin cancer in the military: A systematic review of melanoma and nonmelanoma skin cancer incidence, prevention, and screening among active duty and veteran personnel. J Am Acad Dermatol 2018;78:1185-92.

18. Zink A, Thomé F, Schielein M, et al. Primary and secondary prevention of skin cancer in mountain guides: attitude and motivation for or against participation. J Eur Acad Dermatol Venereol 2018;32:2153-61.

19. Bauer A, Diepgen TL, Schmitt J. Is occupational solar ultraviolet irradiation a relevant risk factor for basal cell carcinoma? A systematic review and meta-analysis of the epidemiological literature. Br J Dermatol 2011;165:612-25.

20. Schmitt J, Diepgen T, Bauer A. Occupational exposure to non-artificial UV-light and non-melanocytic skin cancer a systematic review concerning a new occupational disease. J Dtsch Dermatol Ges 2010;8:250-63, 250-64.

21. Choi K, Lazovich D, Southwell B, et al. Prevalence and characteristics of indoor tanning use among men and women in the United States. Arch Dermatol 2010;146:1356-61.

22. Brem R, Guven M, Karran P. Oxidatively-generated damage to DNA and proteins mediated by photosensitized UVA. Free Radic Biol Med 2017;107:101-9.

23. Brenner M, Hearing VJ. The protective role of melanin against UV damage in human skin. Photochem Photobiol 2008;84:539-49.

24. Parrish JA, Jaenicke KF, Anderson RR. Erythema and melanogenesis action spectra of normal human skin. Photochem Photobiol 1982;36:187-91.

25. Slominski AT, Zmijewski MA, Skobowiat C, et al. Sensing the environment: regulation of local and global homeostasis by the skin's neuroendocrine system. Adv Anat Embryol Cell Biol 2012;212:v, vii, 1-115.

26. Young AR. Chromophores in human skin. Phys Med Biol 1997;42:789-802.

27. Slominski AT, Zmijewski MA, Semak I, et al. Melatonin, mitochondria, and the skin. Cell Mol Life Sci 
2017;74:3913-25.

28. Slominski AT, Chaiprasongsuk A, Janjetovic Z, et al. Photoprotective Properties of Vitamin D and Lumisterol Hydroxyderivatives. Cell Biochem Biophys 2020;78:165-80.

29. Slominski AT, Brożyna AA, Zmijewski MA, et al. The Role of Classical and Novel Forms of Vitamin D in the Pathogenesis and Progression of Nonmelanoma Skin Cancers. Adv Exp Med Biol 2020;1268:257-83.

30. Timerman D, McEnery-Stonelake M, Joyce CJ, et al. Vitamin D deficiency is associated with a worse prognosis in metastatic melanoma. Oncotarget 2017;8:6873-82.

31. Wolff K, Goldsmith L, Katz S, et al. Fitzpatrick's Dermatology in General Medicine, McGrawHill. New York. 2008.

32. Schwartz RA, Bridges TM, Butani AK, et al. Actinic keratosis: an occupational and environmental disorder. J Eur Acad Dermatol Venereol 2008;22:606-15.

33. Slominski A, Wortsman J. Neuroendocrinology of the skin. Endocr Rev 2000;21:457-87.

34. Holick MF. Biological Effects of Sunlight, Ultraviolet Radiation, Visible Light, Infrared Radiation and Vitamin D for Health. Anticancer Res 2016;36:1345-56.

35. Slominski AT, Zmijewski MA, Plonka PM, et al. How UV Light Touches the Brain and Endocrine System Through Skin, and Why. Endocrinology 2018;159:1992-2007.

36. Slominski A, Wortsman J, Tuckey RC, et al. Differential expression of HPA axis homolog in the skin. Mol Cell Endocrinol 2007;265-266:143-9.

37. Slominski A, Wortsman J, Luger T, et al. Corticotropin releasing hormone and proopiomelanocortin involvement in the cutaneous response to stress. Physiol Rev 2000;80:979-1020.

38. Slominski AT, Zmijewski MA, Zbytek B, et al. Key role of CRF in the skin stress response system. Endocr Rev 2013;34:827-84.

39. Bigliardi PL, Dancik Y, Neumann C, et al. Opioids and skin homeostasis, regeneration and ageing - What's the evidence? Exp Dermatol 2016;25:586-91.

40. Slominski A, Wortsman J, Tobin DJ. The cutaneous serotoninergic/melatoninergic system: securing a place under the sun. FASEB J 2005;19:176-94.

41. Slominski AT, Hardeland R, Zmijewski MA, et al. Melatonin: A Cutaneous Perspective on its Production, Metabolism, and Functions. J Invest Dermatol 2018;138:490-9.

42. Slominski AT, Manna PR, Tuckey RC. On the role of skin in the regulation of local and systemic steroidogenic activities. Steroids 2015;103:72-88

43. Nikolakis G, Stratakis CA, Kanaki T, et al. Skin steroidogenesis in health and disease. Rev Endocr Metab Disord 2016;17:247-58.

44. Slominski AT, Li W, Kim TK, et al. Novel activities of CYP11A1 and their potential physiological significance. J Steroid Biochem Mol Biol 2015;151:25-37.

45. Roméro-Graillet C, Aberdam E, Clément $M$, et al. Nitric oxide produced by ultraviolet-irradiated keratinocytes stimulates melanogenesis. J Clin Invest 1997;99:635-42.

46. Yang Z, Misner B, Ji H, et al. Targeting nitric oxide signaling with nNOS inhibitors as a novel strategy for the therapy and prevention of human melanoma. Antioxid Redox Signal 2013;19:433-47.

47. Marzuka AG, Book SE. Basal cell carcinoma: pathogenesis, epidemiology, clinical features, diagnosis, histopathology, and management. Yale J Biol Med 2015;88:167-79.

48. PINKUS H. Premalignant fibroepithelial tumors of skin. AMA Arch Derm Syphilol 1953;67:598-615.

49. de Eusebio E, Sánchez Yus E, López Bran E, et al. Infundibulocystic basaloid neoplasm. J Cutan Pathol 1996;23:147-50.

50. Sloane JP. The value of typing basal cell carcinomas in predicting recurrence after surgical excision. Br J Dermatol 1977;96:127-32.

51. Litzow TJ, Perry HO, Soderstrom CW. Morpheaform basal cell carcinoma. Am J Surg 1968;116:499-505.

52. Lin C, Tripcony L, Keller J, et al. Perineural infiltration of cutaneous squamous cell carcinoma and basal cell carcinoma without clinical features. Int J Radiat Oncol Biol Phys 2012;82:334-40.

53. Kim DP, Kus KJB, Ruiz E. Basal Cell Carcinoma Review. Hematol Oncol Clin North Am 2019;33:13-24.

54. Nagarajan P, Asgari MM, Green AC, et al. Keratinocyte Carcinomas: Current Concepts and Future Research Priorities. Clin Cancer Res 2019;25:2379-91.

55. Kricker A, Armstrong BK, English DR, et al. A doseresponse curve for sun exposure and basal cell carcinoma. Int J Cancer 1995;60:482-8.

56. Moehrle M. Outdoor sports and skin cancer. Clin Dermatol 2008;26:12-5.

57. Lear W, Dahlke E, Murray CA. Basal cell carcinoma: review of epidemiology, pathogenesis, and associated risk factors. J Cutan Med Surg 2007;11:19-30.

58. Liu-Smith F, Jia J, Zheng Y. UV-Induced Molecular Signaling Differences in Melanoma and Non-melanoma Skin Cancer. Adv Exp Med Biol 2017;996:27-40.

59. Seebode C, Lehmann J, Emmert S. Photocarcinogenesis 
and Skin Cancer Prevention Strategies. Anticancer Res 2016;36:1371-8.

60. Afaq F, Syed DN, Malik A, et al. Delphinidin, an anthocyanidin in pigmented fruits and vegetables, protects human $\mathrm{HaCa} \mathrm{T}$ keratinocytes and mouse skin against UVB-mediated oxidative stress and apoptosis. J Invest Dermatol 2007;127:222-32.

61. Hoeijmakers JH. Genome maintenance mechanisms for preventing cancer. Nature 2001;411:366-74.

62. Friedberg EC. DNA damage and repair. Nature 2003;421:436-40.

63. Cline SD, Hanawalt PC. Who's on first in the cellular response to DNA damage? Nat Rev Mol Cell Biol 2003;4:361-72.

64. Branzei D, Foiani M. Regulation of DNA repair throughout the cell cycle. Nat Rev Mol Cell Biol 2008;9:297-308.

65. Kraemer KH, Lee MM, Scotto J. DNA repair protects against cutaneous and internal neoplasia: evidence from xeroderma pigmentosum. Carcinogenesis 1984;5:511-4.

66. Kraemer KH, Lee MM, Andrews AD, et al. The role of sunlight and DNA repair in melanoma and nonmelanoma skin cancer. The xeroderma pigmentosum paradigm. Arch Dermatol 1994;130:1018-21.

67. Sugasawa K, Ng JM, Masutani C, et al. Xeroderma pigmentosum group $\mathrm{C}$ protein complex is the initiator of global genome nucleotide excision repair. Mol Cell 1998;2:223-32.

68. Sugasawa K. UV-induced ubiquitylation of XPC complex, the UV-DDB-ubiquitin ligase complex, and DNA repair. J Mol Histol 2006;37:189-202.

69. Quiñones JL, Demple B. When DNA repair goes wrong: BER-generated DNA-protein crosslinks to oxidative lesions. DNA Repair (Amst) 2016;44:103-9.

70. Suzuki T, Yoshida M, Yamada M, et al. Misincorporation of 2'-deoxyoxanosine 5'-triphosphate by DNA polymerases and its implication for mutagenesis. Biochemistry 1998;37:11592-8.

71. Daya-Grosjean L, Couvé-Privat S. Sonic hedgehog signaling in basal cell carcinomas. Cancer Lett 2005;225:181-92.

72. Varjosalo M, Taipale J. Hedgehog: functions and mechanisms. Genes Dev 2008;22:2454-72.

73. Johnson RL, Rothman AL, Xie J, et al. Human homolog of patched, a candidate gene for the basal cell nevus syndrome. Science 1996;272:1668-71.

74. Bangs F, Anderson KV. Primary Cilia and Mammalian Hedgehog Signaling. Cold Spring Harb Perspect Biol 2017;9:a028175.

75. Otsuka A, Levesque MP, Dummer R, et al. Hedgehog signaling in basal cell carcinoma. J Dermatol Sci 2015;78:95-100.

76. Amakye D, Jagani Z, Dorsch M. Unraveling the therapeutic potential of the Hedgehog pathway in cancer. Nat Med 2013;19:1410-22.

77. Epstein EH. Basal cell carcinomas: attack of the hedgehog. Nat Rev Cancer 2008;8:743-54.

78. Bonilla X, Parmentier L, King B, et al. Genomic analysis identifies new drivers and progression pathways in skin basal cell carcinoma. Nat Genet 2016;48:398-406.

79. Mizuno T, Tokuoka S, Kishikawa M, et al. Molecular basis of basal cell carcinogenesis in the atomic-bomb survivor population: p53 and PTCH gene alterations. Carcinogenesis 2006;27:2286-94.

80. Gailani MR, Ståhle-Bäckdahl M, Leffell DJ, et al. The role of the human homologue of Drosophila patched in sporadic basal cell carcinomas. Nat Genet 1996;14:78-81.

81. Xie J, Murone M, Luoh SM, et al. Activating Smoothened mutations in sporadic basal-cell carcinoma. Nature 1998;391:90-2.

82. Aszterbaum M, Rothman A, Johnson RL, et al. Identification of mutations in the human PATCHED gene in sporadic basal cell carcinomas and in patients with the basal cell nevus syndrome. J Invest Dermatol 1998;110:885-8.

83. Kim MY, Park HJ, Baek SC, et al. Mutations of the p53 and PTCH gene in basal cell carcinomas: UV mutation signature and strand bias. J Dermatol Sci 2002;29:1-9.

84. Jayaraman SS, Rayhan DJ, Hazany S, et al. Mutational landscape of basal cell carcinomas by whole-exome sequencing. J Invest Dermatol 2014;134:213-20.

85. Reifenberger J, Wolter M, Knobbe CB, et al. Somatic mutations in the PTCH, SMOH, SUFUH and TP53 genes in sporadic basal cell carcinomas. Br J Dermatol 2005;152:43-51.

86. Teh MT, Blaydon D, Chaplin T, et al. Genomewide single nucleotide polymorphism microarray mapping in basal cell carcinomas unveils uniparental disomy as a key somatic event. Cancer Res 2005;65:8597-603.

87. Santos DC, Zaphiropoulos PG, Neto CF, et al. PTCH1 gene mutations in exon 17 and loss of heterozygosity on D9S180 microsatellite in sporadic and inherited human basal cell carcinomas. Int J Dermatol 2011;50:838-43.

88. Gailani MR, Leffell DJ, Ziegler A, et al. Relationship between sunlight exposure and a key genetic alteration in basal cell carcinoma. J Natl Cancer Inst 1996;88:349-54. 
89. Huang YS, Bu DF, Li XY, et al. Unique features of PTCH1 mutation spectrum in Chinese sporadic basal cell carcinoma. J Eur Acad Dermatol Venereol 2013;27:235-41.

90. Zhang H, Ping XL, Lee PK, et al. Role of PTCH and p53 genes in early-onset basal cell carcinoma. Am J Pathol 2001;158:381-5.

91. Niyaz M, Khan MS, Mudassar S. Hedgehog Signaling: An Achilles' Heel in Cancer. Transl Oncol 2019;12:1334-44.

92. Pietrobono S, Gagliardi S, Stecca B. Non-canonical Hedgehog Signaling Pathway in Cancer: Activation of GLI Transcription Factors Beyond Smoothened. Front Genet 2019;10:556.

93. Atwood SX, Sarin KY, Whitson RJ, et al. Smoothened variants explain the majority of drug resistance in basal cell carcinoma. Cancer Cell 2015;27:342-53.

94. Wolff F, Loipetzberger A, Gruber W, et al. Imiquimod directly inhibits Hedgehog signalling by stimulating adenosine receptor/protein kinase A-mediated GLI phosphorylation. Oncogene 2013;32:5574-81.

95. Lane DP. Cancer. p53, guardian of the genome. Nature 1992;358:15-6.

96. Aubrey BJ, Strasser A, Kelly GL. Tumor-Suppressor Functions of the TP53 Pathway. Cold Spring Harb Perspect Med 2016;6:a026062.

97. Rady P, Scinicariello F, Wagner RF Jr, et al. p53 mutations in basal cell carcinomas. Cancer Res 1992;52:3804-6.

98. Ziegler A, Leffell DJ, Kunala S, et al. Mutation hotspots due to sunlight in the p53 gene of nonmelanoma skin cancers. Proc Natl Acad Sci U S A 1993;90:4216-20.

99. Tornaletti S, Pfeifer GP. Slow repair of pyrimidine dimers at p53 mutation hotspots in skin cancer. Science 1994;263:1436-8.

100. Rosenstein BS, Phelps RG, Weinstock MA, et al. p53 mutations in basal cell carcinomas arising in routine users of sunscreens. Photochem Photobiol 1999;70:798-806.

101.Barbacid M. ras genes. Annu Rev Biochem 1987;56:779-827.

102. Bos JL. ras oncogenes in human cancer: a review. Cancer Res 1989;49:4682-9.

103. Schwarz T, Beissert S. Milestones in photoimmunology. J Invest Dermatol 2013;133:E7-E10.

104. Chen AC, Halliday GM, Damian DL. Non-melanoma skin cancer: carcinogenesis and chemoprevention. Pathology 2013;45:331-41.

105.Elmets CA, Cala CM, Xu H. Photoimmunology. Dermatol Clin 2014;32:277-90, vii.

106. Kripke ML. Reflections on the field of photoimmunology.
J Invest Dermatol 2013;133:27-30.

107. Ullrich SE. Mechanisms underlying UV-induced immune suppression. Mutat Res 2005;571:185-205.

108. Slominski AT, Zmijewski MA, Semak I, et al. Cytochromes p450 and skin cancer: role of local endocrine pathways. Anticancer Agents Med Chem 2014;14:77-96.

109. D'Orazio J, Jarrett S, Amaro-Ortiz A, et al. UV radiation and the skin. Int J Mol Sci 2013;14:12222-48.

110. Powers JG, Patel NA, Powers EM, et al. Skin Cancer Risk Factors and Preventative Behaviors among United States Military Veterans Deployed to Iraq and Afghanistan. J Invest Dermatol 2015;135:2871-3.

111.Holick MF. Vitamin D deficiency. N Engl J Med 2007;357:266-81.

112.Bikle DD. Vitamin D: an ancient hormone. Exp Dermatol 2011;20:7-13.

113. Pawelek JM, Chakraborty AK, Osber MP, et al. Molecular cascades in UV-induced melanogenesis: a central role for melanotropins? Pigment Cell Res 1992;5:348-56.

114.Jablonski NG, Chaplin G. Colloquium paper: human skin pigmentation as an adaptation to UV radiation. Proc Natl Acad Sci U S A 2010;107 Suppl 2:8962-8.

115.Slominski A, Tobin DJ, Shibahara S, et al. Melanin pigmentation in mammalian skin and its hormonal regulation. Physiol Rev 2004;84:1155-228.

116. Becklund BR, Severson KS, Vang SV, et al. UV radiation suppresses experimental autoimmune encephalomyelitis independent of vitamin D production. Proc Natl Acad Sci U S A 2010;107:6418-23.

117. Skobowiat C, Dowdy JC, Sayre RM, et al. Cutaneous hypothalamic-pituitary-adrenal axis homolog: regulation by ultraviolet radiation. Am J Physiol Endocrinol Metab 2011;301:E484-93.

118. Skobowiat C, Slominski AT. UVB Activates HypothalamicPituitary-Adrenal Axis in C57BL/6 Mice. J Invest Dermatol 2015;135:1638-48.

119. Skobowiat C, Postlethwaite AE, Slominski AT. Skin Exposure to Ultraviolet B Rapidly Activates Systemic Neuroendocrine and Immunosuppressive Responses. Photochem Photobiol 2017;93:1008-15.

120. Rokohl AC, Kopecky A, Guo Y, et al. Surgical resection with ophthalmoplastic reconstruction : Gold standard in periocular basal cell carcinoma. Ophthalmologe 2020;117:95-105.

121. Kakkassery V, Loeffler KU, Sand M, et al. Current diagnostics and therapy recommendations for ocular basal cell carcinoma. Ophthalmologe 2017;114:224-36.

122. Work Group; Invited Reviewers; Kim JYS, et al. 
Guidelines of care for the management of basal cell carcinoma. J Am Acad Dermatol 2018;78:540-59.

123. Chren MM, Linos E, Torres JS, et al. Tumor recurrence 5 years after treatment of cutaneous basal cell carcinoma and squamous cell carcinoma. J Invest Dermatol 2013;133:1188-96.

124. Holt PJ. Cryotherapy for skin cancer: results over a 5 -year period using liquid nitrogen spray cryosurgery. Br J Dermatol 1988;119:231-40.

125.Kuflik EG, Gage AA. The five-year cure rate achieved by cryosurgery for skin cancer. J Am Acad Dermatol 1991;24:1002-4.

126. Thissen MR, Neumann MH, Schouten LJ. A systematic review of treatment modalities for primary basal cell carcinomas. Arch Dermatol 1999;135:1177-83.

127. Roozeboom MH, Aardoom MA, Nelemans PJ, et al. Fractionated 5-aminolevulinic acid photodynamic therapy after partial debulking versus surgical excision for nodular basal cell carcinoma: a randomized controlled trial with at least 5-year follow-up. J Am Acad Dermatol 2013;69:280-7.

128. Choudhary S, Tang J, Elsaie ML, et al. Lasers in the treatment of nonmelanoma skin cancer. Dermatol Surg 2011;37:409-25.

129. Moskalik K, Kozlov A, Demin E, et al. The efficacy of facial skin cancer treatment with high-energy pulsed neodymium and Nd:YAG lasers. Photomed Laser Surg 2009;27:345-9.

130. Cognetta AB, Howard BM, Heaton HP, et al. Superficial $\mathrm{x}$-ray in the treatment of basal and squamous cell carcinomas: a viable option in select patients. J Am Acad Dermatol 2012;67:1235-41.

131. Delishaj D, Rembielak A, Manfredi B, et al. Nonmelanoma skin cancer treated with high-dose-rate brachytherapy: a review of literature. J Contemp Brachytherapy 2016;8:533-40.

132.Love WE, Bernhard JD, Bordeaux JS. Topical imiquimod or fluorouracil therapy for basal and squamous cell carcinoma: a systematic review. Arch Dermatol 2009; 145:1431-8.

133. Bianchi L, Orlandi A, Campione E, et al. Topical treatment of basal cell carcinoma with tazarotene: a clinicopathological study on a large series of cases. Br J Dermatol 2004;151:148-56.

134. Siller G, Rosen R, Freeman M, et al. PEP005 (ingenol mebutate) gel for the topical treatment of superficial basal cell carcinoma: results of a randomized phase IIa trial. Australas J Dermatol 2010;51:99-105.
135. Brinkhuizen T, Frencken KJ, Nelemans PJ, et al. The effect of topical diclofenac $3 \%$ and calcitriol $3 \mu \mathrm{g} / \mathrm{g}$ on superficial basal cell carcinoma (sBCC) and nodular basal cell carcinoma (nBCC): A phase II, randomized controlled trial. J Am Acad Dermatol 2016;75:126-34.

136. Kirby JS, Miller CJ. Intralesional chemotherapy for nonmelanoma skin cancer: a practical review. J Am Acad Dermatol 2010;63:689-702.

137.Pricl S, Cortelazzi B, Dal Col V, et al. Smoothened (SMO) receptor mutations dictate resistance to vismodegib in basal cell carcinoma. Mol Oncol 2015;9:389-97.

138. Sekulic A, Migden MR, Oro AE, et al. Efficacy and safety of vismodegib in advanced basal-cell carcinoma. N Engl J Med 2012;366:2171-9.

139. Basset-Seguin N, Hauschild A, Grob JJ, et al. Vismodegib in patients with advanced basal cell carcinoma (STEVIE): a pre-planned interim analysis of an international, openlabel trial. Lancet Oncol 2015;16:729-36.

140.Migden MR, Guminski A, Gutzmer R, et al. Treatment with two different doses of sonidegib in patients with locally advanced or metastatic basal cell carcinoma (BOLT): a multicentre, randomised, double-blind phase 2 trial. Lancet Oncol 2015;16:716-28.

141.Hou X, Rokohl AC, Ortmann M, et al. Effective treatment of locally advanced periocular basal cell carcinoma with oral hedgehog pathway inhibitor? Graefes Arch Clin Exp Ophthalmol 2020;258:2335-7.

142.Fellner C. Vismodegib (erivedge) for advanced Basal cell carcinoma. P T 2012;37:670-82.

143. Sekulic A, Migden MR, Lewis K, et al. Pivotal ERIVANCE basal cell carcinoma (BCC) study: 12-month update of efficacy and safety of vismodegib in advanced BCC. J Am Acad Dermatol 2015;72:1021-6.e8.

144. Basset-Séguin N, Hauschild A, Kunstfeld R, et al. Vismodegib in patients with advanced basal cell carcinoma: Primary analysis of STEVIE, an international, open-label trial. Eur J Cancer 2017;86:334-48.

145.Edwards BJ, Raisch DW, Saraykar SS, et al. Hepatotoxicity with Vismodegib: An MD Anderson Cancer Center and Research on Adverse Drug Events and Reports Project. Drugs R D 2017;17:211-8.

146.Lear JT, Migden MR, Lewis KD, et al. Long-term efficacy and safety of sonidegib in patients with locally advanced and metastatic basal cell carcinoma: 30-month analysis of the randomized phase 2 BOLT study. J Eur Acad Dermatol Venereol 2018;32:372-81.

147. Novartis. ODOMZO®(sonidegib) capsules, for oral use: US Prescribing Information. 2015. Available online: 
http://www.accessdata.fda.gov/

148. Glaser R, Andridge R, Yang EV, et al. Tumor site immune markers associated with risk for subsequent basal cell carcinomas. PLoS One 2011;6:e25160.

149. Wong DA, Bishop GA, Lowes MA, et al. Cytokine profiles in spontaneously regressing basal cell carcinomas. Br J Dermatol 2000;143:91-8.

150.Kaporis HG, Guttman-Yassky E, Lowes MA, et al. Human basal cell carcinoma is associated with Foxp $3+\mathrm{T}$ cells in a Th2 dominant microenvironment. J Invest Dermatol 2007;127:2391-8.

151.Elamin I, Zecević RD, Vojvodić D, et al. Cytokine concentrations in basal cell carcinomas of different histological types and localization. Acta Dermatovenerol Alp Pannonica Adriat 2008; 17:55-9.

152.Pellegrini C, Orlandi A, Costanza G, et al. Expression of IL-23/Th17-related cytokines in basal cell carcinoma and in the response to medical treatments. PLoS One 2017;12:e0183415.

153. Nardinocchi L, Sonego G, Passarelli F, et al. Interleukin-17 and interleukin-22 promote tumor progression in human nonmelanoma skin cancer. Eur J Immunol 2015;45:922-31.

154. Falchook GS, Leidner R, Stankevich E, et al. Responses of metastatic basal cell and cutaneous squamous cell carcinomas to anti-PD1 monoclonal antibody REGN2810. J Immunother Cancer 2016;4:70.

155. Hauschild A, Eichstaedt J, Möbus L, et al. Regression of melanoma metastases and multiple non-melanoma skin cancers in xeroderma pigmentosum by the PD1-antibody pembrolizumab. Eur J Cancer 2017;77:84-7.

156.Lipson EJ, Lilo MT, Ogurtsova A, et al. Basal cell carcinoma: PD-L1/PD-1 checkpoint expression and tumor regression after PD-1 blockade. J Immunother Cancer 2017;5:23.

157.Bakshi A, Chaudhary SC, Rana M, et al. Basal cell carcinoma pathogenesis and therapy involving hedgehog signaling and beyond. Mol Carcinog 2017;56:2543-57.

158. Reichrath J, Nürnberg B. Cutaneous vitamin D synthesis versus skin cancer development: The Janus faces of solar UV-radiation. Dermatoendocrinol 2009;1:253-61.

doi: $10.21037 /$ fomm-21-31

Cite this article as: Fan W, Rokohl AC, Guo Y, Chen H, Gao T, Kakkassery V, Heindl LM. Narrative review: mechanism of ultraviolet radiation-induced basal cell carcinoma. Front Oral Maxillofac Med 2023;5:9.
159. Martens MC, Seebode C, Lehmann J, et al. Photocarcinogenesis and Skin Cancer Prevention Strategies: An Update. Anticancer Res 2018;38:1153-8.

160. Gritz ER, Tripp MK, de Moor CA, et al. Skin cancer prevention counseling and clinical practices of pediatricians. Pediatr Dermatol 2003;20:16-24.

161. Chen AC, Martin AJ, Choy B, et al. A Phase 3 Randomized Trial of Nicotinamide for Skin-Cancer Chemoprevention. N Engl J Med 2015;373:1618-26.

162.Surjana D, Halliday GM, Martin AJ, et al. Oral nicotinamide reduces actinic keratoses in phase II doubleblinded randomized controlled trials. J Invest Dermatol 2012;132:1497-500.

163. Chen AC, Martin AJ, Dalziell RA, et al. A phase II randomized controlled trial of nicotinamide for skin cancer chemoprevention in renal transplant recipients. $\mathrm{Br}$ J Dermatol 2016;175:1073-5.

164. Elmets CA, Viner JL, Pentland AP, et al. Chemoprevention of nonmelanoma skin cancer with celecoxib: a randomized, double-blind, placebo-controlled trial. J Natl Cancer Inst 2010;102:1835-44.

165. Muranushi C, Olsen CM, Green AC, et al. Can oral nonsteroidal antiinflammatory drugs play a role in the prevention of basal cell carcinoma? A systematic review and metaanalysis. J Am Acad Dermatol 2016;74:108-119.e1.

166.Lang BM, Balermpas P, Bauer A, et al. S2k Guidelines for Cutaneous Basal Cell Carcinoma - Part 2: Treatment, Prevention and Follow-up. J Dtsch Dermatol Ges 2019;17:214-30.

167.Soltani-Arabshahi R, Tristani-Firouzi P. Chemoprevention of nonmelanoma skin cancer. Facial Plast Surg 2013;29:373-83.

168. Wolfe CM, Green WH, Cognetta AB Jr, et al. A possible chemopreventive role for photodynamic therapy in Gorlin syndrome: a report of basal cell carcinoma reduction and review of literature. Australas J Dermatol 2013;54:64-8.

169. Bichakjian CK, Olencki T, Aasi SZ, et al. Basal Cell Skin Cancer, Version 1.2016, NCCN Clinical Practice Guidelines in Oncology. J Natl Compr Canc Netw 2016;14:574-97. 